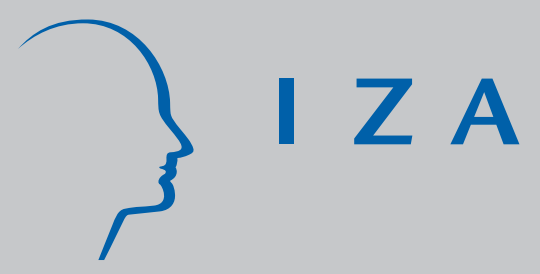

IZA DP No. 3448

Interethnic Marriage:

A Choice between Ethnic and Educational Similarities

Delia Furtado

Nikolaos Theodoropoulos

April 2008 


\title{
Interethnic Marriage: A Choice between Ethnic and Educational Similarities
}

\author{
Delia Furtado \\ University of Connecticut \\ and IZA \\ Nikolaos Theodoropoulos \\ University of Cyprus \\ and CReAM, UCL
}
Discussion Paper No. 3448
April 2008

IZA

P.O. Box 7240

53072 Bonn

Germany

Phone: +49-228-3894-0

Fax: +49-228-3894-180

E-mail: iza@iza.org

\begin{abstract}
Any opinions expressed here are those of the author(s) and not those of IZA. Research published in this series may include views on policy, but the institute itself takes no institutional policy positions.

The Institute for the Study of Labor (IZA) in Bonn is a local and virtual international research center and a place of communication between science, politics and business. IZA is an independent nonprofit organization supported by Deutsche Post World Net. The center is associated with the University of Bonn and offers a stimulating research environment through its international network, workshops and conferences, data service, project support, research visits and doctoral program. IZA engages in (i) original and internationally competitive research in all fields of labor economics, (ii) development of policy concepts, and (iii) dissemination of research results and concepts to the interested public.
\end{abstract}

IZA Discussion Papers often represent preliminary work and are circulated to encourage discussion. Citation of such a paper should account for its provisional character. A revised version may be available directly from the author. 


\section{ABSTRACT}

\section{Interethnic Marriage: A Choice between Ethnic and Educational Similarities*}

This paper examines the effects of education on intermarriage, and specifically whether the mechanisms through which education affects intermarriage differ by immigrant generation, age at arrival, and race. We consider three main paths through which education affects marriage choice. First, educated people may be better able to adapt to different cultures making them more likely to marry outside of their ethnicity (cultural adaptability effect). Second, because the educated are less likely to reside in ethnic enclaves, meeting potential spouses of the same ethnicity may be difficult (enclave effect). Lastly, if spouse-searchers value similarities in education as well as similarities in ethnicity, then the effect of education will depend on the availability of same-ethnicity potential spouses with a similar level of education (assortative matching effect). Using data from the 2000 U.S. Census, we find that controlling for the enclave effect, there is empirical evidence for both the cultural adaptability and assortative matching effects. Our estimates also suggest that assortative matching is relatively more important for the native born rather than the foreign born, for the foreign born that arrived young rather than old, and for Asians rather than Hispanics. We provide additional evidence suggestive of our hypotheses and discuss policy implications.

JEL Classification: J12, I21, J61

Keywords: ethnic intermarriage, education, immigration

Corresponding author:

Delia Furtado

Department of Economics

University of Connecticut

341 Mansfield Road

Unit 1063

Storrs, CT 06269-1063

USA

E-mail: Delia.Furtado@uconn.edu

\footnotetext{
* The authors gratefully acknowledge comments and suggestions provided by Yoo-Mi Chin, S. Djajic, Andrew Foster, Rachel Friedberg, Kaivan Munshi, Irina Paley, Shannon Seitz, Almudena Sevilla-Sanz, Stephen Trejo, Myeong-Su Yun, and the participants in the University of Connecticut's Brown Bag Workshop. The usual caveat applies.
} 


\section{Introduction}

There is a large literature on whether immigrants in the U.S. today are assimilating at the same speed and through the same processes as immigrants in the past. Much of this literature either directly or implicitly points to the importance of social integration in their economic assimilation. Because the racial and educational composition of the latest wave of immigration differs so much from the native population, an important question is whether this social integration is becoming more difficult.

Traditionally, social scientists have measured social integration using residential segregation (Duncan and Lieberson, 1959 and Peach, 2005). However, a growing number of papers consider a different measure of social integration: interethnic marriage. That is, marriage to a person belonging to a different ethnic group.

In a series of papers, Borjas (1992, 1995, 1998 and 2006) shows theoretically and empirically how ethnic capital, measured by the average skill level in an ethnic group, affects the productivity of workers in the next generation. He finds that although part of the human capital externality generated by this ethnic capital is simply a proxy for the average human capital in the neighborhoods in which the children of immigrants grow up, ethnic capital also has its own independent effect (Borjas, 1995). Children growing up in the same neighborhood may have different outcomes depending on their ethnic group simply because they are more exposed to people who share their ethnic background.

As suggested by Borjas' work, immigrants choose with whom to associate. Since these choices potentially depend on their levels of human capital, it is important to examine how education affects ethnic attachment. If, for example, immigrants with high education levels do not associate with co-ethnics, then they will not be affected by the ethnic externality and their human capital will not contribute to the externality. We show in this paper that the relationship between education and ethnic attachment also depends on the average skill level of a person's ethnic group as well as his nativity, age at arrival, and race.

We determine a person's ethnic attachment by looking at whom he decides to marry. Certainly, inhabitants of ethnic enclaves have many fellow ethnics in their social circles and so are more likely to marry someone with the same ancestry even just by chance. At the same time, the ethnic preferences of people living far from an enclave yet remaining closely attached to their ethnic groups, can still be captured by their marriage to someone of the same ethnicity. ${ }^{1}$ In fact, because communication and transportation costs have decreased so much in the past century, the ethnic composition of one's neighborhood may have become relatively less important in predicting the ethnic composition of one's social circle. Surely, marriage to someone with the same country of origin remains an important measure of ethnic attachment since it is not only a result of having many fellow ethnics in one's social circle, but also a cause. In fact, intermarriage has been referred to as the "final step" in the immigrant assimilation process (Gordon, 1964).

\footnotetext{
${ }^{1}$ We use the words ethnicity and ancestry interchangeably throughout the paper.
} 
Ethnic intermarriage has long been studied by sociologists, ${ }^{2}$ but a growing number of economists have also started considering its causes and consequences. Bisin and Verdier (2000) present a theoretical analysis of the role of an ethnic group's share of the population on intermarriage decisions, while Bisin et al. (2004) empirically test hypotheses from that analysis using data on religious intermarriages. Furtado (2006) examines the mechanisms through which education affects intermarriage. Celikaksoy et al. (2006) analyze the importance of assortative matching on education in marriage choices of immigrants in Denmark. Meng and Gregory’s (2005) paper on the causal effects of intermarriage on earnings of immigrants in Australia led to similar analyses for the U.S. (Kantarevic, 2005) and France (Meng and Meurs, 2006). Using various identification strategies, Furtado (2007), van Ours and Veenman (2007) and Skyt Nielsen et al. (2007) examine the effects of intermarriage on education levels of immigrants or their children in the U.S., in the Netherlands, and in Denmark, respectively. Using German survey data, Dustmann (1996) finds that marriage to a native increases social assimilation as measured by feelings of national identity. Duncan and Trejo (2006), uses the negative relationship between human capital and intermarriage rates for Mexican Americans along with the finding that children with intermarried parents are less likely to be identified as Mexican to suggest that observed measures of intergenerational progress for Mexican Americans may be biased. Card et al. (2000) use intermarriage rates as a measure of intergenerational assimilation rates of immigrants. Angrist (2002) uses changes in immigration policy in the U.S. as a source of exogenous variation to explain ethnic endogamy rates of second-generation immigrants in the U.S.

Wong (2003) examines three competing explanations (mating taboo, individual differences in endowments and limited opportunities for courtship between blacks and whites) for the low intermarriage rates between blacks and whites in the U.S. She finds that the main contributor to the low intermarriage rate between blacks and whites is the mating taboo. Similarly, Furtado (2006) proposes three mechanisms through which education could affect intermarriage. These are: a) the cultural adaptability effect, b) the enclave effect and c) the assortative matching effect. The cultural adaptability effect suggests that educated people are better able to adapt to different customs and cultures. Since immigrants with more human capital have a better "technology" for adapting to the host society, they are more likely to marry natives. The enclave effect suggests that educated immigrants are more likely to move out of their ethnic enclaves because, for example, they have larger geographic labor markets. They are, therefore, less likely to meet potential spouses of their own ethnicity and so, naturally, they are less likely to marry them. Lastly, the assortative matching effect posits that marriage surplus increases when education levels of husband and wife are similar. This implies that given a costly search process, educated immigrants may be willing to substitute similarities in ethnicity for similarities in education.

\footnotetext{
${ }^{2}$ See among others, Kalmijn (1991, 1993, 1998); Lewis and Oppenheimer (2000); Lichter et al. (1992); Lichter et al. (2007), Lieberson and Waters (1988); Qian (1997, 1999); Qian and Lichter (2001, 2007); Qian et al. (2001).
} 
Using 1970 U.S. Census data, Furtado (2006) finds that controlling for the enclave effect, assortative matching is more important than cultural adaptability in explaining marriage choices of second-generation immigrants. This conclusion may not be applicable today because the composition of immigrants has since changed so dramatically. First, immigrants and their children make up a larger proportion of the U.S. population. In 1970, 16.5 percent of the population was either foreign born or had at least one foreign born parent while in 2000, the figure increased to 20.4 percent. In 1980, the proportion foreign born was 6.2 percent, but grew to 10.4 percent by 2000, the highest proportion since 1930 (Schmidley, 2001). A continuously replenished supply of potential sameethnicity spouses could certainly affect marriage decisions.

Moreover, newer cohorts of immigrants have very different levels of education than natives. Although they are just as likely as natives to have a bachelor's degree or above, immigrants are much less likely to have a high school diploma and are significantly less likely to have graduated the 9th grade (Larsen, 2004). Also, immigrants today have a very different racial composition. In 1970, the great majority of immigrants were from Europe. Today, while a little over half of the foreign born are from Latin America and a quarter are Asian (Larsen, 2004), only about 12.5 percent of the U.S. population is Hispanic and 3.6 percent is Asian (Grieco and Cassidy, 2001).

A direct comparison between second-generation immigrants in 1970 and 2000 is not possible because 1970 was the last year the Census asked for parents' country of birth. However, this paper first tests whether the conclusions drawn for second-generation immigrants in 1970 (Furtado, 2006) apply to all people that list at least one ancestry in the 2000 Census. Next, we examine how assimilation affects the relationship between education and intermarriage decisions by, first, running the analysis separately on the native-born and foreign born. Then, for the foreign born, we look at how age at migration affects marriage decisions. This paper also adds race to the study of intermarriage. Even though they are becoming more frequent, interracial marriages are still relatively rare. Preferences for marriage within one's race may change the relative importance of the cultural adaptability and assortative matching effects.

Using the 2000 U.S. Census, we find that even after controlling for the enclave effect, there is evidence for both the cultural adaptability and assortative matching effects. As one may expect, the cultural adaptability effect is relatively more important for the foreign born than for the native-born. Assortative matching is relatively more important for immigrants that are less attached to the U.S., as measured by their age at arrival. There are also significant differences by race in the relative importance of education in endogamy. More specifically, assortative matching plays a greater role in the marriage decisions of Asians than of Hispanics, at least for the foreign born. These results are consistent with the hypothesis that relative to low education racial groups, groups that place a high value on education tend to prefer similarities in education with their spouses over similarities in ethnicity.

The remainder of the paper is organized as follows. Section 2 provides a theoretical background and explains the empirical strategy. The subsequent section presents the data and highlights some descriptive statistics. Section 4 discusses the empirical results. 
Section 5 provides a robustness check by employing an alternative approach for arriving at the same conclusions. Section 6 concludes, provides policy implications, and suggests avenues for future research.

\section{Theoretical Background and Methods}

Since Becker (1973), economists have thought about marriage market participants matching on characteristics that are complements in household production. Becker cites education and ethnic origin as examples of such complementary traits. Lam (1988) extends this analysis by considering the joint consumption of household public goods as an explanation for assortative matching. Since demands for many household public goods depend on ethnicity as well as education, Lam's analysis also implies that marriage market participants should match on these traits. ${ }^{3}$ Since spouse search is costly, however, optimal matches do not always occur. We use this basic framework in describing three possible mechanisms through which education affects marriage choice: the cultural adaptability effect, the enclave effect, and the assortative matching effect.

We start by assuming that, all else equal, people prefer to match with someone who shares a similar culture. As in Lazear (1999), we think of culture as a "notion of shared values, beliefs, expectations, customs, jargon, and rituals". The cultural adaptability effect suggests that educated people are better able to adapt to different customs or to communicate their potentially different expectations and beliefs to their spouses. Because of this better "technology" for adapting to a different culture, they become more likely to marry outside of their ethnic group. Thus, by the cultural adaptability effect, regardless of their ethnic group, more education decreases the probability of marrying within ethnicity.

The enclave effect suggests that the educated are less likely to live in ethnic enclaves because, for example, they have larger geographic labor markets (Bartel, 1989). If there are fewer co-ethnics within close geographic proximity, the probability of encountering an acceptable same-ethnicity spouse purely by random chance decreases and thus the costs of meeting someone with the same ethnic background increases. This could be a reason why the educated are less likely to marry endogamously. By the enclave effect, an increase in education results in moving away from ethnic enclaves. When the proportion of same-ethnicity potential spouses living within close geographic proximity decreases, the costs associated with finding a same ethnicity spouse increases. We capture this idea in the empirical specification by controlling for the size of a person's ethnic group living within close geographic proximity.

Lastly, consistent with both the Becker (1973) and Lam (1988) theories of marriage, the assortative matching effect posits that marriage surplus increases when education levels

\footnotetext{
${ }^{3}$ For example, demand for family vacations to the homeland will certainly be affected by ancestry. Also, demand for visits to museums or even 'intellectual conversations" could be affected by education (Furtado, 2006).
} 
of husband and wife are similar. ${ }^{4}$ This implies that given a costly search process, educated immigrants may be willing to substitute similarities in ethnicity for similarities in education. By the assortative matching effect, an increase in education will lead to an increase in endogamy for people living in cities where the average education in their ethnic groups is above the average in the general population. For people in low education groups, an increase in education will lead to a decrease in endogamy.

All of these ideas are incorporated into the following linear probability model ${ }^{5}$ :

$$
y_{i j k}=\beta_{0}+\beta_{1} h_{i j k}+\beta_{2} h_{i j k}\left(\bar{h}_{j k}-\bar{h}_{a k}\right)+\beta_{3} p_{j k}+\beta_{4} p_{j k}^{2}+\beta_{5} X_{i j k}+\gamma_{j}+\varepsilon_{i j k}
$$

where $y_{i j k}$ is an indicator variable equal to one if person $i$ in ethnicity $j$ living in geographical area $k$ has an endogamous marriage and zero otherwise. Years of schooling is denoted $h$. Average schooling in ethnic group $j$ in city $k$ is denoted $\bar{h}_{j k}$ while $\bar{h}_{a k}$ measures the average schooling of the general population in geographical area $k$. Ethnic group size is denoted $p$ while $X$ is a vector of characteristics which capture tastes for marrying within ethnicity, such as age, language ability, and whether the person lives in the central part of the city. If education affects endogamy through the cultural adaptability mechanism, then we expect that $\beta_{1}$ is negative. If education affects endogamy through the assortative matching mechanism, then we expect that $\beta_{2}$ is positive. Although we do not have a direct measure for the enclave effect, we control for it by including $p$ and its square term in the specification.

The vector of controls cannot capture all of the possible attributes correlated with both education and preferences for endogamy. For a variety of reasons, some ethnic groups may have fewer cultural differences with the average American and so it may be easier for them to share a household with an American. Also, some ethnic groups have a long history of immigration to the U.S. (for example, Mexicans) while others had a big wave of immigration at a certain time and then immigration stopped rather suddenly (for example, Italians). This history of immigration from a certain country could affect its social institutions in the U.S. Social institutions such as festivals and social clubs may make finding an acceptable ethnic spouse easier. In order to capture all of these effects, ethnic group fixed effects, denoted $\gamma$, are included in the model.

After evaluating the relative importance of the different mechanisms linking education to endogamy for all people that list an ancestry in the Census, we examine how the magnitudes of the effects vary for different populations. One would expect that with more attachment to the U.S., similarities in education with a potential spouse should become relatively more important than similarities in ethnic traits. Thus, running the

\footnotetext{
${ }^{4}$ Alternatively, we can assume that marriage market participants always prefer more education in a spouse to less. Equilibrium sorting in the marriage market will still result in assortative matching on education and ethnicity.

${ }^{5}$ We ran all specifications in the paper using a probit model and the results were qualitatively the same.
} 
model on immigrants and natives separately, the coefficient capturing the assortative matching effect, $\beta_{2}$, should be greater for the native-born than for the foreign born.

Predictions for the coefficient measuring cultural adaptability, $\beta_{1}$, are more difficult to make. With more assimilation, ethnic preferences should decrease. For this reason, it could be that education has less of an effect on marriage decisions and so $\beta_{1}$ will decrease in magnitude. In the extreme case, if people have no preference for marrying within ethnicity, education certainly cannot decrease this preference. On the other hand, if ethnic preferences are strong enough, they may not be sensitive to education and again, $\beta_{1}$ may be very close to zero.

Comparing the native-born to the foreign born is a rather crude method for evaluating the effect of assimilation on marriage patterns. A more precise measure of assimilation, at least for the foreign born, could be years since migration. However, it is impossible with our data set to establish years since migration at the time immigrants were making marriage decisions. Moreover, it is difficult to determine whether the foreign born arrived in the U.S. already married. Instead, we compare marriage patterns of immigrants that arrived at different ages, limiting our analysis to those that arrived under the age of 18 , and thus most likely unmarried.

Using U.S. data, Friedberg (1993) and Borjas (1995) find that age at arrival has a negative effect on earnings even after controlling for several demographics. ${ }^{6}$ There is a large psychology literature which finds that because of physiological changes in the brain, age at arrival in a new country is critical for the language acquisition of immigrants (Bleakley and Chin, 2007). Because of the large literature linking language acquisition to many other measures of assimilation, we feel justified in using age at arrival as a proxy for assimilation. We compare marriage patterns of immigrants that came when they were younger than five to the immigrants that arrived between the ages of 14 and 17, inclusively. Both sets of immigrants were very likely exposed to the U.S. marriage market, but those that came very young probably value shared ethnicity with their spouses less than those that arrived as teenagers. As described above, our main hypothesis is that the assortative matching coefficient, $\beta_{2}$, is larger in magnitude for the immigrants that arrived at a young age. Although our predictions for $\beta_{1}$ are not perfectly clear, we suspect that the ethnic preferences of childhood immigrants are not immutable and so $\beta_{1}$ will be smaller in magnitude for immigrants that arrived at a younger age.

Race may also affect the mechanisms through which education affects endogamy decisions. Since so many of the new immigrants are either Hispanic or Asian, we consider their marriages in particular. Although certain Asian and Hispanic ethnic groups have a long history of migration to the U.S., the level of migration has never been

\footnotetext{
${ }^{6}$ Schaafsma and Sweetman (2001) reach the same conclusion using Canadian data. They present three reasons for the negative relationship between age at immigration and earnings: a) schooling and work experience in the home country do not have as high returns in the host country, b) older immigrants face more difficulty in dealing with the linguistic and cultural changes, and c) education in the host country decreases with age at arrival and this leads to an indirect effect on earnings.
} 
what it is today. This continued migration from Asia and Latin America replenishes marriage markets making it easier for native born racial minorities to find acceptable same-race spouses. Consistent with this idea, intermarriage between natives and foreign born minorities increased in the 1990s while interracial marriages between Latinos and Whites and Asians and Whites slightly decreased (Bean and Stevens, 2003).

The model sociologists typically use to explain interracial marriages is Merton's (1941) social exchange theory. Put simply, the theory is that Whites bare a cost for marrying a lower status racial group, and so will only intermarry if they are compensated with some other favourable characteristic in a spouse, such as income or education. One prediction of the theory is that black males with high socioeconomic status will marry white females with lower socioeconomic status. Although the model seems to work reasonably well for black-white marriages, the model is not as successful in explaining who marries whom in Hispanic and Asian marriages. In fact, there is more endogamy for high education Asians than low education Asians (Qian, 1997). Also, the white men that marry Asian women have higher levels of education than the Asian men that marry Asian women (Qian, 1997).

Fryer (2007) interprets the finding that Blacks who intermarry have less education than those who intramarry as evidence against the social exchange theory. He finds Becker's theory of optimal matches in the marriage market to be the most consistent with the data on interracial marriages. Applying the marriage market model to interracial marriages, he concludes that if interracial marriage is costly and education in a spouse is important, then interracial marriages may be infrequent, but those that intermarry will be the highly educated.

Using this basic framework, we can make predictions about the mechanisms through which education affects endogamy separately for Whites, Hispanics, and Asians. It is useful to keep in mind that because the majority of the U.S. population is non-Hispanic white, a decision not to marry within ethnicity for Hispanics and Asians, often implies an interracial marriage. Thus, given that marriage outside of one's race is more difficult than a same-race interethnic marriage, it is easier for Whites to intermarry than for minorities to intermarry. This implies that intermarriage decisions of Whites are likely to be more sensitive to changes in education than minorities. Concerning Hispanics and Asians, our main hypothesis is that racial groups that place a higher value on educational attainment may prefer similarities in education with their spouses over similarities in ancestry. The Asian ethnic economy highly rewards education gains in Asian children (Qian et al., 2001), while Hispanics lag behind other races in educational attainment (Lichter et al., 2007). This suggests that assortative matching on education is more important for Asians than Hispanics. Thus, we expect that $\beta_{2}$ is greater for Asians than for Hispanics.

Without insight into the differential social costs to interracial marriage or the relationship between education and these social costs, predictions concerning the cultural adaptability 
effect are more difficult. ${ }^{7}$ In fact, among Asians, the impact of education on interracial marriage decisions is weakest for the Japanese, the most assimilated ethnic group, and the Southeast Asians, the least assimilated Asian group (Qian, 1997). This is consistent with the Japanese having little preference for endogamous marriage and so education cannot have a substantial effect, while Southeast Asians have such a strong preference for endogamy that education does not have a strong effect. We do not feel comfortable in making any predictions about the magnitude of $\beta_{1}$ for different racial groups.

\section{The Data}

The analysis uses the 5 percent Public Use Sample of the 2000 U.S. Census as reported by the Integrated Public Use Microdata Series (IPUMS) (Ruggles et al., 2004). ${ }^{8}$ This data set is particularly well suited for our purposes because it allows us to get reasonably accurate counts of the number of immigrants from a specific country of origin living within close geographic proximity (Glazer, 2005).

The sample is restricted to married males, who report a single race, have a spouse present and live in an identifiable metropolitan statistical area (MSA) and in an identifiable metro area. We drop married men with spouses away from home. Only legally married couples are considered since Census data do not allow us to accurately identify cohabitating couples. ${ }^{9}$ In order to limit the possibility of reverse causality between education and endogamy, only those over the age of 25 and not enrolled in school are used in the analysis. Even without putting this restriction on the data, only 15 percent of all married people acquire more education post-marriage (Lewis and Oppenheimer, 2000). ${ }^{10}$ People over the age of 40 are also eliminated from the sample in order to reduce bias resulting from the fact that endogamous marriages are less likely to end in divorce (Kalmijn, 1998). As discussed in Qian and Lichter (2007), young married couples are less likely to have been divorced or remarried. Also, only ancestry groups from non-English speaking countries with more than 1,000 observations are considered in the analysis.

A marriage is considered endogamous if spouses share a common ancestry. Census respondents were allowed to write in as many as two ancestries. Our dependent variable takes the value of one if the first ancestry of the husband is the same as the first ancestry

\footnotetext{
${ }^{7}$ There is some evidence that the social costs of marrying Whites may be higher for Asians than Hispanics (Lichter et al., 2007). In fact, interracial marriages between Asians and Whites were banned in many states, but marriages between Hispanics and whites have never been illegal (Fryer, 2007).

${ }^{8}$ The data set is publicly available at http://usa.ipums.org/usa/. Appendix B provides details on all of the variables used in the analysis. We discuss the survey questions as well as the construction of the variables.

${ }^{9}$ Qian and Lichter (2007) suggest that there is little evidence that cohabitation has become a substitute for marriage for interracial couples.

${ }^{10}$ Since most people do not acquire much schooling after the age of 25 and only have children after getting married, we experimented with dropping from the sample those who had their first child younger than age 25. Results were robust.
} 
listed by the wife and zero otherwise. ${ }^{11}$ Although ancestry corresponds very closely to country of birth for immigrants, the interpretation of this variable is more difficult for the native born. For example, Duncan and Trejo (2006) argue that, precisely because of the relationship between education and intermarriage, highly educated descendents of Mexicans may be less likely to identify themselves as Mexican than the less educated descendents of Mexicans. Ideally, we would use information on parents' and grandparents' countries of birth, but this is not available in the data.

In the 2000 Census, education is measured in academic qualifications and not in years of schooling. We construct a continuous years of schooling variable by mapping educational qualifications into the average number of years it takes for people to complete them, following Chiswick and DebBurman (2004). The size of the ethnic group is obtained by dividing the number of people from that ethnic group residing in the MSA by the MSA population. We count both populations using the appropriate person weights. To limit sampling error in the formation of these variables, observations are dropped if there are fewer than 50 people from a person's ethnic group living in his MSA.

The controls used in the analysis are language ability, age cohort dummies, residence in the center city, veteran status, region of residence, and race. The racial categories are based on self-responses in census questionnaires. Although Hispanic was not listed as a race in the Census form, we coded respondents as Hispanic if they answered yes to the Hispanic question, regardless of how they answered the race question. Because there are not enough immigrant Blacks we drop this racial group from the sample.

All tables with results from the descriptive and the multivariate analysis are shown in Appendix A. Table 1 presents descriptive statistics for males in endogamous and exogamous marriages separately. Intermarried males have more years of schooling, belong to high-skilled ethnic groups, and live in cities with a smaller proportion of people with the same ancestry. They are more likely to be native born, speak only English, and have fought in a war, but are less likely to live in the central part of the city. Table 2 shows endogamy rates, ethnic group sizes, and average education levels by ancestry. Endogamy rates are higher for groups that are racial minorities and for groups that are highly represented in the cities in which members of the group reside.

\section{Empirical Results}

Table 3 presents estimates of the effects of education on endogamy. Standard errors are adjusted for clustering within MSA-ancestry cells. All specifications include a set of controls to capture ethnic preferences. Coefficients on the controls have the expected signs: Speaking only English decreases endogamy as does being born in the U.S. Perhaps because the military exposes its members to people from many different backgrounds,

\footnotetext{
${ }^{11}$ We also considered marriages of people that list only one ancestry and results were robust. We repeat the analysis for those individuals who reported only their second ancestry and, again, results were qualitatively the same.
} 
veterans are less likely to marry endogamously. Also, perhaps because preferences for marriage within ethnicity have decreased over the past century, older people are more likely to be in endogamous marriages. Males between the ages of 31 and 35 have higher endogamy rates than those between the ages of 26 and 30, while 36 to 40 year olds have the highest endogamy rates. These results are consistent with Fryer's (2007) findings that veterans and younger people are more likely to be in interracial marriages. Residing in an ethnic enclave makes it easier to meet potential spouses of the same ethnicity. Moreover, people with greater preferences for ethnic endogamy are more likely to live in ethnic enclaves. Thus, because ethnic enclaves tend to be located in center cities, residence in the central part of a city tends to increase endogamy relative to living outside the central city. Central city status unknown is the omitted category. Non-Hispanic Whites are less likely to be endogamous than Hispanics while Asians are more likely than Hispanics to marry within ethnicity. Racial minorities are more endogamous than non-Hispanic Whites. Eight region dummies are also included in all specifications.

Table 3 shows that even with this set of controls, a one year increase in schooling is associated with a 1 percentage point decrease in the probability of marrying someone with the same ancestry. As discussed in the previous section, this coefficient on education is an average effect of the different mechanisms through which education could affect endogamy decisions. By adding the size of the ethnic group living in a person's city, we control for the possibility that people with more education are less likely to live in ethnic enclaves and so even by random matching, they may become less likely to marry endogamously. Column 2 shows that the effect of education is cut in half when measures for the size of the ethnic group are added to the specification. This suggests that the enclave effect is an important mechanism through which education affects endogamy. For instance, an increase in the size of the ethnic group results in an increase in endogamy.

In Column 3, the assortative matching effect is accounted for by adding the interaction of education and the difference between average ethnic education and average education of Americans in the person's city. When this measure of the availability of co-ethnics with a similar education is included in the analysis, the coefficient on education alone stays about the same while the coefficient on the interaction has the expected positive sign. An F test suggests that the three education variables are also jointly significantly different from zero. Taken together, these effects suggest that although education in general has a negative effect on endogamy, more education tends to decrease endogamy more for people living in areas where average ethnic education is lower than the average American education. Conversely, for people living in areas where ethnics have higher education levels than others in the local population, an increase in education leads to a smaller decrease in endogamy. In fact, for people in ethnic groups with very high average levels of education relative to the general population, an increase in education can lead to an increase in endogamy. We interpret this result as evidence of assortative matching on education in the marriage market.

Ancestry fixed effects are added in Column 4. Instead of exploiting variation in average education levels across ethnic groups and across cities, we look within ethnic groups to 
see how the effect of education responds to differences in relative education levels between ethnics and natives across different cities (Brien, 1997). Note that the coefficients on education alone and the interaction remain approximately the same.

We conclude that there is support for all three mechanisms through which education affects endogamy. In the final specification, regression results suggest that when average ethnic education equals average education for the general population, a one year increase in schooling results in a 0.3 percentage point decrease in the probability of marrying endogamously. As the average ethnic education falls below the average for the general population by one year, education further decreases endogamy by 0.2 percentage points. On the other hand, if average ethnic education is above the general population average, then education will not decrease endogamy by as much. In fact, if the ethnic average is greater than the general average by more than a year and a half, then an increase in education will result in an increase in endogamy.

Although the magnitudes of these coefficients may appear small, they can imply rather large differences in endogamy because there is substantial variation in the difference in education means across cities and ethnic groups. For example, for a Mexican living in Washington, DC where Mexicans have on average 9.3 fewer years of schooling than the rest of the population, a one year increase in education leads to a 2.2 percentage point decrease in the probability of endogamy. If they were to increase their schooling levels by the 9.3 years, their endogamy rate would decrease by 20.5 percentage points. Meanwhile, for a Russian living in Long Beach, CA where the average education difference is 3.9 , the same increase in education results in a 0.5 percentage point increase in the probability of endogamy. ${ }^{12}$

One may believe that much of the assortative matching result is driven by college completion. We ran a specification adding an interaction between college completion and our assortative matching interaction. This triple interaction had the significant and positive effect suggesting that college completers may have a strong preference for marrying other college graduates. However, they are not the only drivers of the assortative matching effect since the coefficient on the original interaction remains significant.

A potential problem with this analysis is that people choose where to live. In the fixed effects model, identification is coming from variation across MSAs in the difference between average education in a person's ethnic group and average education for the population as a whole. Conceivably, there could be a relationship between own education and the average ability of co-ethnics where a person chooses to live, and this relationship

\footnotetext{
${ }^{12}$ There are other measures of the availability of same-ethnicity spouses with a similar level of education. One example is the proportion of all people with the same level of education that shares the same ancestry. Using this proxy instead of the education interaction to measure assortative matching, did not change the qualitative results of our analysis. Another measure we considered takes into account the fact that people do not only marry within their education category. For each person, we found the probability that someone with that person's level of education marries another person in each of the education categories. Next, we calculated the proportion of people in each education category that shares the person's ethnicity. We then weighted these proportions using the education probabilities. Again, results were robust.
} 
could be correlated with ethnic preferences in a manner which could bias the assortative matching coefficient. Presumably, average education in one's ethnic group in the entire country is more exogenous in that people cannot choose it. We ran a regression exploiting only differences in average education levels across ancestries and results did not change qualitatively. This is not our preferred specification because using this method of identification, we cannot control for ethnicity fixed effects. Thus, unobservable preferences for endogamy which vary by ancestry and are correlated with the ethnic group's average education may lead to biased results. In order to be problematic, ethnic groups with both very high and very low average levels of education would need to have the highest unobservable ethnic preferences. Since this is a possibility, caution must be used in interpreting coefficients in specifications without ethnicity fixed effects. Still, even though both methods of identification are imperfect, they are imperfect for different reasons, and so the fact that results are robust supports our findings.

As discussed in Furtado (2006), another potential concern with this analysis lies in the interpretation of the size of the ethnic group in an MSA as a measure of the ease at which spouse-searchers meet potential spouses with the same ancestry. There are two problems with this approach. First, we measure the size of the ethnic group in the person's MSA of residence at the time of the survey as opposed to the time and place where the person was actually searching for a spouse. Since location decisions of couples may be affected by their marriage decisions, coefficients may be biased. Second, even if we could measure the size of the ethnic group at the right time and place, ethnics with higher preferences for endogamy are more likely to live in ethnic enclaves while searching for a spouse. Thus, the coefficient on the size of the ethnic group would be measuring both opportunity and preferences for intramarriage. Since the focus of this paper is on disentangling the cultural adaptability effect from the assortative matching effect while controlling for the enclave effect as well as preferences, the second issue is not a significant problem for our purposes. Nevertheless, we deal with both of these issues, at least for the native born population, by calculating the size of the ethnic group in a person's state of birth as opposed to MSA of current residence. Since one's state of birth is chosen by one's parents, it is arguably less endogenous to marriage choice. Moreover, it is certainly not subject to reverse causality concerns. Qualitative results do not change when this different measure is used. When using state of birth as opposed to current residence, we are not controlling for the enclave effect and so this is not our preferred specification. However, knowledge that our coefficients of interest are not sensitive to our measure of opportunity makes us less concerned about endogeneity bias.

The results in Table 3 show how education affects marriage decisions for all people that list at least one ancestry in the Census. However, the relative importance of the different mechanisms through which education affects endogamy could differ depending on how assimilated a person is to the U.S. culture. Table 4 shows the fixed effects specification, separately for the native born and for immigrants that arrive in the U.S. at different ages. Specifically, Column 1 limits the sample to the native born while Column 2 includes only the foreign born. As expected, the relative importance of assortative matching is higher for populations with greater attachment to the U.S. The coefficient on the interaction is five times the size for the native born as it is for the foreign born. This suggests that 
natives value similarities in education with their spouses more than immigrants. The fact that the coefficient on education alone is larger in magnitude for the native born than the foreign born is consistent with the hypothesis that immigrants have such strong preferences for endogamous marriage that these preferences are not sensitive to changes in education.

The interpretation of the coefficients is difficult in both of these samples. The native born sample includes second-generation immigrants, whose parents may have arrived in the U.S. only shortly before they were born, as well as people whose families have been in the country for several generations. On the other hand, the immigrant sample surely includes immigrants that arrived in the U.S. already married and so their marriage decisions would not be as influenced by the educational distribution of potential spouses in the U.S. To deal with these concerns, we limit the sample to the foreign born, but examine how intermarriage decisions differ depending on their age at arrival. Table 4, Column 3 presents results for those that arrived below the age of five. Column 4 limits the sample to the foreign born that arrived between the ages of 14 and 17, inclusively. The last column includes immigrants that arrived as adults.

Interestingly, as seen in Column 3, there is no support for the cultural adaptability effect for immigrants that arrive very young while there is support for the assortative matching effect. This is consistent with Furtado (2006) who found no evidence for the cultural adaptability effect for second-generation immigrants, the native-born children of immigrants, with two foreign born parents. Conversely, for immigrants that arrive as teenagers, there is no support for the importance of assortative matching, but education does seem to decrease preferences for marriage within ethnicity.

In the last great wave of immigration, immigrants were predominantly from European countries and so were of the same race as most natives. Today about half of the foreign born are Hispanic and about a quarter are Asian. As discussed in the previous section of this paper, the marriage patterns of people of different races may respond differently to changes in education.

Table 5 presents results separately by racial group and nativity. For the foreign born, the evidence suggests that assortative matching on education is most important for Whites. This may be at least partially explained by the fact that Whites are the majority group. The more abundant supply of same-race potential spouses may make it easier to substitute educational similarities with a spouse for ethnic similarities. For racial minorities, however, this trade-off may prove more difficult. Consider, for example, the case of a Vietnamese bachelor in a city with few Asians but where average Vietnamese education is significantly below the average education for the general population. Then, even if more education would make him willing to trade similarities in ancestry for similarities in education, it may be difficult for him to find an Asian spouse with the ideal education level. Even if there are many Whites in the city with the ideal education level, the additional costs of interracial marriage over and above the costs of interethnic marriage may not make the substitution worthwhile. Thus, it is not surprising that the coefficient on the education interaction for Whites is larger than that for minorities. 
Comparing foreign born racial minorities, however, we find that the assortative matching coefficient is very close to zero and insignificant for Hispanics while it is positive and significant for Asians. This is consistent with the hypothesis that racial groups that place a higher value on education are more willing to sacrifice ethnicity for education when evaluating potential spouses.

The cultural adaptability effect, as measured by the coefficient on education, is strongest for foreign born Whites followed by Hispanics. The coefficient is not statistically significant for Asians. This implies that even if average education in a person's ethnic group is equal to the average education for the general population, an increase in education will lead to the biggest decrease in endogamy for Whites and Hispanics, but no change for Asians. As discussed previously, there are many possible explanations for this. It could be that racial groups that respond most drastically to education have the highest endogamy preferences to start with, and so there is more room for education to make these preferences less important. Alternatively, it may be that groups with the strongest ethnic preferences are less sensitive to chances in education. In Section 5, we present suggestive evidence that, relative to education, Hispanics have the strongest ethnic preferences, followed by Whites and then Asians.

It is difficult to interpret coefficients for the foreign born because they may have arrived in the U.S. already married. Table 5 also compares regression results by race for the native born. For Asians and Hispanics, the coefficient on the education interaction is larger for the native born than for the foreign born. This makes sense in that, relative to the foreign born, the native born should value similarities in education over similarities in ethnicity. We do not see this relationship for Whites. However, it is important to keep in mind that only one cross-section of data is used in this analysis and so the native and foreign born belong to different cohorts of immigrants.

For the native born, the assortative matching coefficient is approximately the same for all racial groups ${ }^{13}$, suggesting that racial differences in the importance of matching on education relative to ethnicity disappear rather quickly. However, racial differences in the cultural adaptability effect remain for the native born. If we hold the average ethnic education equal to average education for the population in general, then an increase in education will lead to a bigger drop for Hispanics than Whites. There is no statistically significant impact for Asians.

\footnotetext{
${ }^{13}$ The coefficient on the interaction has the same magnitude for Asians and Hispanics, but is not statistically significant for Asians. We suspect this is due to the relatively small sample size of native born Asians.
} 


\section{An Alternative Approach to Inferring Preferences for Ethnic Endogamy and Assortative Matching}

Our results suggest that there is a role for both the cultural adaptability and the assortative matching effects in marriage markets. We provide evidence that assortative matching is relatively more important for the native born than for the foreign born. It is also more important for the foreign born that arrived young rather than old and for Asians rather than Hispanics. In this section, we present an alternative technique suggestive of the assortative matching hypothesis. After establishing the importance of similarities in education in evaluating potential spouses, we introduce evidence suggestive of a method for inferring the relative preferences for endogamy of different groups. The results provide a context for interpreting the relationships between the coefficients found in the previous section.

The main idea behind the assortative matching effect is that people prefer their spouses to be of the same ethnicity and have similar education levels. However, if search is costly (as in, Furtado 2006), marriage market participants may be willing to marry someone with a different level of education but the same ancestry or someone with the same education level but a different ancestry. This implies that at equilibrium, the absolute value of the difference in spousal education levels should be greater for intramarried couples than intermarried couples. ${ }^{14}$ Moreover, the difference in spousal education differences between endogamous and exogamous couples should be greater for groups with higher ethnic preferences. In other words, the greater the importance of ethnic endogamy, the more of an education difference one is willing to tolerate in a spouse.

To test these hypotheses, we focus on a sample which is most likely to have high preferences for both ethnic endogamy and assortative matching on education: the foreign born that arrived before the age of 14 . These immigrants were certainly exposed to the U.S. marriage market. Because they are foreign born, they most likely have high ethnic preferences. At the same time, since they came at a young age, they do not face the language and cultural barriers in marrying outside of their ethnic group. Table 6 shows average (absolute values of) spousal differences in years of schooling by marriage type. As predicted, there are bigger educational differences between spouses in endogamous marriages than in exogamous marriages.

If we had data on ethnic preferences, we could test the hypothesis that the higher these preferences, the more of an education difference marriage market participants are willing to accept in a spouse. Although we do not have data on ethnic preferences, we argue that certain categories of immigrants have higher ethnic preferences. Specifically, immigrants that arrived older, with poorer English skills, and living in ethnic enclaves presumably have the highest preferences for ethnic endogamy. Thus, they should be willing to sacrifice the most in terms of educational similarities with their spouses. Table 6 presents

\footnotetext{
${ }^{14}$ This assumes that the education distributions are very similar across ethnic groups. If they are different, then just by random matching, endogamous marriages should have smaller spousal differences in education. This makes our test for assortative matching even stronger.
} 
average spousal educational differences separately by whether immigrants arrived before or after the age of 5 . Consistent with the assortative matching hypothesis, intermarried couples have smaller differences in their years of schooling. Consistent with the hypothesis that older arriving immigrants have greater preferences for endogamy, the difference between endogamous and exogamous couples is greatest for immigrants that arrived older. Similarly, spousal differences in education are relatively greater in endogamous couples than in exogamous couples for immigrants with poorer English skills.

The size of one's ethnic group living within close proximity has a theoretically ambiguous effect on the relationship between spousal educational differences and marriage type. On the one hand, a greater availability of same-ancestry spouses makes it easier to find a spouse with the same ethnicity and education level. On the other hand, immigrants with high ethnic preferences are more likely to live in ethnic enclaves. Thus, we may expect the difference in spousal education differences between endogamous and exogamous marriages to be greatest for immigrants living in MSAs with high concentrations of people sharing their ethnic background. Table 6 shows that, in fact, the greater availability of same-ethnicity spouses does not eliminate the need to sacrifice educational similarities for ethnic similarities. The difference between endogamous and exogamous couples is greatest for people living in cities where more than eight percent of residents share the spouse-searcher's ethnicity. ${ }^{15}$

This approach provides further support to our findings that racial groups that are more education oriented, like Asians, are more willing to sacrifice ethnic similarities for educational similarities in a spouse. As can be seen in Table 6, the difference in spousal educational differences between endogamous and exogamous couples is greatest for Hispanics and virtually nonexistent for Asians. This suggests that Hispanics have more of a preference for marrying endogamously than Asians and even Whites. Thus, we attribute the small presence of the cultural adaptability effect for Asians to their lack of ethnic preferences relative to education preferences. Table 6 suggests that Hispanics have high ethnic preferences and this may explain why the cultural adaptability effect is larger for Hispanics than for Asians. That is, since Hispanics have higher preferences for endogamy, it is easier for education to change the importance of having a same-ethnicity spouse. If Asians do not have a strong preference for endogamy to start with, then it is not surprising that education does not change the relative importance of having an ethnic spouse.

\section{Conclusions}

This paper provides evidence of three different mechanisms through which education affects interethnic marriage decisions. On average, education decreases endogamy for all people that identify with a specific ancestry. However, the negative relationship is not

\footnotetext{
${ }^{15}$ Eight percent is the median value for the size of the ethnic group in the MSA for this sample.
} 
quite as strong after controlling for the probability of encountering someone with the same ethnic background within close geographic proximity. This is consistent with the idea that people with more education are less likely to live in or near ethnic enclaves. Lastly, we show that the availability of co-ethnics with a similar level of education is also a significant determinant of interethnic marriage decisions, highlighting the role of assortative matching on education.

The relative importance of these mechanisms differs for various populations. Assortative matching on education is relatively more important for people that are more culturally and economically attached to the U.S. Specifically, the native born seem to value similarities in education more than similarities in ethnicity relative to the foreign born. Also, assortative matching on education seems to be more important for immigrants that arrived in the U.S. at a young age. There are also racial differences in the relative importance of assortative matching. Although Whites seem to be the most willing to substitute ethnic traits for education in a spouse, this may be because Whites are the majority racial group in the U.S. and so the substitution is simply easier to make. While native born Hispanics and Asians value matching on education about equally, foreign born Asians value education in a spouse more than Hispanics. On the other hand, the cultural adaptability effect is stronger for foreign born Hispanics than foreign born Asians. We also provide suggestive evidence that, relative to education, Asians value shared ancestry with a spouse less than Whites and Hispanics. This may be because of the importance of education in Asian culture.

We conclude that not only is education an important determinant of intermarriage decisions, but that there are several mechanisms linking education and spouse-choice and that the relative importance of these mechanisms differs by nativity, race, and age at arrival for the foreign born. If we assume that marriage to someone with a different ancestry is a measure of a person's association with natives more generally, then there are several policy implications that might be drawn from this analysis.

In determining which immigrants are allowed into the country, countries with point systems of immigration like Canada, Australia, and recently, the UK tend to put more weight on years of schooling and language ability than countries, such as the U.S., without point systems. Part of the rationale for this is that more educated immigrants tend to assimilate economically and socially faster than non-educated immigrants. This paper reinforces this idea by finding a generally negative relationship between education and ethnic endogamy. If highly educated immigrants are less likely to associate with people with their ethnic background and the Borjas externality story is true, then this suggests that highly educated immigrants are not as subject to ethnic externalities as low education immigrants. Moreover, the low education immigrants do not benefit as much from the positive ethnic externalities from the high education immigrants in their ethnic group.

Another important finding of this paper is that the effect of education differs by immigrant group. Assortative matching on education implies that in low education ethnic groups, more education leads to more association with natives while in high education ethnic groups, more education results in less association with natives. Thus, ethnic 
externalities imply an especially slow rate of social assimilation for low education immigrants in low education ethnic groups. Our assortative matching results also suggest that, all else equal, highly educated immigrants in high education groups socially assimilate more slowly than low education immigrants in these groups. In other words, for immigrants in high education groups living in areas with low-education Americans, more education may even lead to a decrease in social integration.

If the social integration of immigrants is a policy goal, our findings suggest that, all else equal, given two immigrants with the same education, more points should be given to the immigrant in the low education ethnic group than to an immigrant in a group whose average education is similar to U.S. average education levels. In a similar way, the findings that the relative importance of assortative matching depends on nativity, age at arrival, and race can also inform policy discussions.

More generally, the marriage patterns of immigrants and their descendents may also have effects on household fertility and employment decisions. These decisions, in turn, affect wages and schooling levels of both immigrants and the natives that compete with them. In addition, differences in assortative matching on education influence human capital levels of children of these marriages, thus potentially affecting inequality. These are fruitful topics left for future research.

\section{References}

Angrist, J. (2002). How do sex ratios affect marriage markets and labor markets? Evidence from Americas second generation, Quarterly Journal of Economics, Vol. 117, pp. 997-1038.

Bartel, A.P. (1989). Where do the new U.S. immigrants live? Journal of Labor Economics, Vol. 7, pp. 371-91.

Bean F.D. and Stevens G. (2003). America's newcomers and the dynamics of diversity, Russell Sage Foundation, New York.

Becker, G.S. (1973). A theory of marriage: Part I, Journal of Political Economy, Vol. 81, pp. 813-846.

Bisin, A, Topa, G. and Verdier, T. (2004). Religious intermarriage and socialization in the United States, Journal of Political Economy, Vol. 112, pp. 615-664.

Bisin, A. and Verdier, T. (2000). Beyond the melting pot: cultural transmission, marriage, and the evolution of ethnic and religious traits, Quarterly Journal of Economics, Vol. 115, pp. 955-988. 
Bleakley, H.C. and Chin, A. (2007). English proficiency and social assimilation among immigrants: an instrumental variables approach, CCIS Working Paper No. 149.

Borjas, G.J. (1992). Ethnic capital and intergenerational mobility, Quarterly Journal of Economics, Vol. 107, pp. 123-150.

Borjas, G.J. (1995). Ethnicity, neighborhoods, and human capital externalities, American Economic Review, Vol 85, pp. 365-390.

Borjas, G.J. (1998). To ghetto or not to ghetto: ethnic and residential segregation, Journal of Urban Economics, Vol. 44, pp. 228-253.

Borjas, G.J. (2006). Making it in America: social mobility in the immigrant population, The Future of Children, Vol. 16, pp. 55-71.

Brien, M.J. (1997). Racial differences in marriage and the role of marriage markets, Journal of Human Resources, Vol. 32, pp. 741-778.

Card, D., Dinardo, J.E. and Estes, E. (2000). The more things change: immigrants and the children of immigrants in the 1940s, the 1970s, and the 1990s, in G. Borjas editor, 'Issues in the Economics of Immigration', Chicago: University of Chicago Press.

Celikaksoy, A., Skyt Nielsen, H. and Verner, M. (2006). Marriage migration: just another case of positive assortative matching?, Review of Economics of the Household, Vol. 4, pp. 253-275.

Chiswick, B. and DebBurman, N. (2004). Educational attainment: analysis by immigrant generation, Economics of Education Review, Vol. 23, pp. 361-379.

Duncan, O.D. and Lieberson, S. (1959). Ethnic segregation and assimilation, American Journal of Sociology, Vol. 64, pp. 364-374.

Duncan, B. and Trejo, S. (2007). Ethnic identification, intermarriage, and unmeasured progress by Mexican Americans, forthcoming in G.J. Borjas, ed., Mexican Immigration, Chicago: University of Chicago Press, 2007.

Dustmann, C. (1996). The social assimilation of immigrants, Journal of Population Economics, Vol. 9, pp. 37-54.

Friedberg, R. M. (1993). The labor market assimilation of immigrants in the US: The role of age at arrival. Brown University mimeo, March.

Fryer, Jr. R.G. (2007). Guess who's coming to dinner? Trends in interracial marriages over the $20^{\text {th }}$ century, Journal of Economic Perspectives, Vol. 21, pp. 71-90.

Furtado, D. (2006). Human capital and interethnic marriage decisions, IZA DP. No. 1989. 
Furtado, D. (2007). Cross-Nativity Marriages, Gender, and Human Capital Levels of Children, Working Paper 2007-33, University of Connecticut, Department of Economics.

Glazer, N. (2005). American diversity and the 2000 Census, in "Ethnicity, Social Mobility and Public Policy: Comparing the U.S. and the UK”, Edited by Loury, G. Modood, T and Teles, S. (2005), Cambridge.

Gordon, M. M. (1964). Assimilation in American Life. Oxford University Press, New York.

Grieco E. M. and Cassidy R. C. (2001). Overview of race and Hispanic origin. Census 2000 Brief series. U.S. Census Bureau, March.

Kalmijn, M. (1998). Intermarriage and homogamy: causes, patterns, trends, Annual Review of Sociology, Vol. 24, pp. 395-421.

Kalmijn, M. (1993). Spouse selection among the children of European immigrants: a comparison of marriage cohorts in the 1960 Census, International Migration Review, Vol. 727, pp. 51-78.

Kalmijn, M. (1991). Shifting boundaries: trends in religious and educational homogamy, American Sociological Review, Vol. 56, pp. 786-800.

Kantarevic, J. (2005). Interethnic marriages and economic assimilation of immigrants, Unpublished manuscript.

Lam, D. (1988). Marriage markets and assortative mating with household public goods: theoretical reasons and empirical implications, Journal of Human Resources, Vol. 23, pp. 462-487.

Larsen, L. J. (2004). The foreign-born population in the United States: 2003. Current Population Reports, P20-551, U.S. Census Bureau, Washington, D.C.

Lazear, E.P. (1999). Culture and language, Journal of Political Economy, Vol. 107, pp. S95-S126.

Lewis, S.K. and Oppenheimer, V.K. (2000). Educational assortative mating across marriage markets: non-Hispanic whites in the United States, Demography, Vol. 37, pp. 29-40.

Lichter D.T., McLaughlin, D.K., Kephart, G. and Landry, D.J. (1992). Race and the retreat from marriage: a shortage of marriageable men, American Sociological Review, Vol. 57, pp. 781-799. 
Lichter D.T., Brown, J.B., Qian, Z. and Carmalt, J.H. (2007). Marital assimilation among Hispanics: evidence of declining cultural and economic incorporation, Social Science Quarterly, Vol. 88, pp. 746-765.

Lieberson, S. and Waters, M.C. (1988). From many strands: ethnic and racial groups in contemporary America, New York: Russell Stage Foundation.

Meng, X. and Gregory, R.G. (2005). Intermarriage and the economic assimilation of immigrants, Journal of Labor Economics, Vol. 23, 135-175.

Meng, X. and Meurs, D. (2006). Intermarriage, language, and economic assimilation process: a case study of France, IZA DP. No. 2461.

Merton, R. K. (1941). Intermarriage and the Social Structure: Fact and Theory, Psychiatry, Vol. 4, pp. 361-374.

Peach, C. (2005). Social integration and social mobility: spatial segregation and intermarriage of the Caribbean population in Britain, in "Ethnicity, Social Mobility and Public Policy: Comparing the U.S. and the UK”, Edited by Loury, G. Modood, T and Teles, S. (2005), Cambridge.

Qian, Z. (1997). Breaking the racial barriers: variations in interracial marriage between 1980 and 1990, Demography, Vol. 34, pp. 263-276.

Qian, Z. (1999). Who intermarries? Education, nativity, region and interracial marriage, 1980 and 1990, Journal of Comparative Family Studies, Vol. 30, pp. 579-597.

Qian, Z., Blair, S. and Ruf, S.D. (2001). Asian American interracial and interethnic marriages: differences by education and nativity, International Migration Review, Vol. 35, pp. 557-586.

Qian, Z. and Lichter, D. (2001). Measuring marital assimilation: intermarriage among natives and immigrants, Social Science Research, Vol. 30, pp. 289-312.

Qian, Z. and Lichter, D. (2007). Social boundaries and marital assimilation: interpreting trends in racial and ethnic intermarriage, American Sociological Review, Vol. 72, pp. 6894.

Ruggles, S., Matthew Sobek, Trent Alexander, Catherine A. Fitch, Ronald Goeken, Patricia Kelly Hall, Miriam King, and Chad Ronnander. Integrated Public Use Microdata Series: Version 3.0 [Machine-readable database]. Minneapolis, MN: Minnesota Population Center [producer and distributor], 2004.

Schaafsma J. and Sweetman A. (2001). Immigrant earnings: age at immigration matters, Canadian Journal of Economics, Vol. 34, pp. 1066-1099. 
Schmidley, D. (2001). Profile of the foreign born population in the United States: 2000, Current Population Reports, Special Studies, Series P23-206.

Skyt Nielsen, S., Smith, N. and Celikaksoy, A. (2007). The effect of marriage on education of immigrants: evidence from a policy reform restricting spouse import, IZA DP. No. 2899.

van Ours, J.C. and Veenman, J. (2007). How interethnic marriages affect the educational attainment of children; evidence from a natural experiment, Unpublished manusript.

Wong, L. (2003). Why do only 5.5\% of black men marry white women?, International Economic Review, Vol. 44, pp. 803-806. 


\section{APPENDIX A}

Table 1. Descriptive statistics of selected variables.

\begin{tabular}{lrrrrrrr}
\hline & \multicolumn{2}{c}{ Exogamous Couples } & & \multicolumn{2}{c}{ Endogamous Couples } & & \multicolumn{2}{c}{$\begin{array}{l}\text { All } \\
\text { Mean }\end{array}$} & $\begin{array}{l}\text { Standard } \\
\text { Deviation }\end{array}$ & Mean & $\begin{array}{l}\text { Standard } \\
\text { Deviation }\end{array}$ & Mean & $\begin{array}{l}\text { Standard } \\
\text { Deviation }\end{array}$ \\
\hline \hline Years of education & 14.12 & 0.008 & 12.71 & 0.014 & 13.54 & 0.008 \\
Age & 34.54 & 0.010 & 34.40 & 0.013 & 34.48 & 0.008 \\
Size of ethnic group in MSA & 0.09 & 0.000 & 0.13 & 0.000 & 0.10 & 0.000 \\
Mean ethnic education in MSA & 13.99 & 0.004 & 12.66 & 0.008 & 13.44 & 0.004 \\
Mean education in MSA & 13.80 & 0.002 & 13.60 & 0.002 & 13.72 & 0.001 \\
Speaks only English & 0.85 & 0.001 & 0.42 & 0.002 & 0.67 & 0.001 \\
White & 0.83 & 0.001 & 0.42 & 0.002 & 0.66 & 0.001 \\
Asian & 0.02 & 0.000 & 0.15 & 0.001 & 0.08 & 0.001 \\
Hispanic & 0.14 & 0.001 & 0.41 & 0.002 & 0.25 & 0.001 \\
U.S. born & 0.88 & 0.001 & 0.48 & 0.002 & 0.71 & 0.001 \\
Veteran & 0.13 & 0.001 & 0.07 & 0.001 & 0.11 & 0.001 \\
In metro area, central city & 0.14 & 0.001 & 0.21 & 0.001 & 0.17 & 0.001 \\
In metro area, outside central city & 0.50 & 0.001 & 0.44 & 0.002 & 0.47 & 0.001 \\
\hline
\end{tabular}

Notes: Figures are weighted. 
Table 2. Endogamy Rate, Size of Ethnic Group, and Average Education Level by Ancestry.

\begin{tabular}{|c|c|c|c|c|}
\hline Ancestry & Endogamy & $\begin{array}{l}\text { Size of Ethnic Group } \\
\text { in MSA }\end{array}$ & $\begin{array}{l}\text { Mean Ethnic Education } \\
\text { in MSA }\end{array}$ & Mean Education in MSA \\
\hline Austrian & 0.046 & 0.003 & 15.86 & $\overline{13.93}$ \\
\hline Belgian & 0.061 & 0.008 & 14.73 & 13.82 \\
\hline Danish & 0.061 & 0.010 & 15.09 & 13.91 \\
\hline Dutch & 0.142 & 0.036 & 14.32 & 13.79 \\
\hline Finnish & 0.116 & 0.010 & 14.78 & 13.95 \\
\hline French & 0.146 & 0.033 & 13.98 & 13.76 \\
\hline German & 0.342 & 0.172 & 14.35 & 13.84 \\
\hline Greek & 0.200 & 0.007 & 14.30 & 13.91 \\
\hline Irish & 0.272 & 0.092 & 14.46 & 13.89 \\
\hline Italian & 0.266 & 0.100 & 14.18 & 13.88 \\
\hline Norwegian & 0.126 & 0.051 & 14.69 & 13.98 \\
\hline Portuguese & 0.345 & 0.057 & 11.96 & 13.59 \\
\hline Swedish & 0.069 & 0.021 & 14.98 & 13.90 \\
\hline Swiss & 0.094 & 0.005 & 15.38 & 13.86 \\
\hline Czechoslovakian & 0.065 & 0.007 & 15.03 & 13.85 \\
\hline Hungarian & 0.072 & 0.010 & 14.60 & 13.83 \\
\hline Lithuanian & 0.068 & 0.004 & 15.34 & 13.90 \\
\hline Polish & 0.199 & 0.055 & 14.42 & 13.87 \\
\hline Russian & 0.346 & 0.017 & 16.57 & 13.93 \\
\hline Yugoslavian & 0.195 & 0.001 & 13.82 & 13.70 \\
\hline Spaniard & 0.324 & 0.007 & 13.24 & 13.54 \\
\hline Mexican & 0.754 & 0.191 & 9.73 & 13.15 \\
\hline Central American & 0.574 & 0.011 & 9.70 & 13.49 \\
\hline South American & 0.550 & 0.010 & 12.94 & 13.78 \\
\hline Puerto Rican & 0.525 & 0.026 & 12.17 & 13.80 \\
\hline Cuban & 0.539 & 0.152 & 13.11 & 13.44 \\
\hline West Indies & 0.623 & 0.018 & 11.99 & 13.88 \\
\hline Hispanic & 0.514 & 0.017 & 11.92 & 13.45 \\
\hline Asian Indian & 0.873 & 0.019 & 16.52 & 13.97 \\
\hline Chinese & 0.821 & 0.030 & 14.83 & 13.90 \\
\hline Filipino & 0.747 & 0.036 & 14.52 & 13.71 \\
\hline Japanese & 0.584 & 0.037 & 15.66 & 13.80 \\
\hline Korean & 0.868 & 0.014 & 15.23 & 13.71 \\
\hline Vietnamese & 0.838 & 0.014 & 12.52 & 13.73 \\
\hline
\end{tabular}

Notes: Figures are weighted. 
Table 3. Effects of Education on Endogamy.

\begin{tabular}{|c|c|c|c|c|}
\hline Endogamy & 1 & 2 & 3 & 4 \\
\hline Years of Education & $\begin{array}{c}-0.008 \\
(0.001)^{* *}\end{array}$ & $\begin{array}{c}-0.004 \\
(0.001)^{* *}\end{array}$ & $\begin{array}{c}-0.003 \\
(0.001)^{* *}\end{array}$ & $\begin{array}{c}-0.003 \\
(0.001)^{* *}\end{array}$ \\
\hline Mean Ethnic Education & -- & -- & $\begin{array}{l}-0.003 \\
(0.004)\end{array}$ & $\begin{array}{c}-0.006 \\
(0.003)+\end{array}$ \\
\hline Mean Ethnic Education-Mean Education & --- & --- & $\begin{array}{c}-0.036 \\
(0.007)^{* *}\end{array}$ & $\begin{array}{c}-0.032 \\
(0.005)^{* *}\end{array}$ \\
\hline Education $\times$ (Mean Ethnic Education-Mean Education) & --- & --- & $\begin{array}{c}0.002 \\
(0.000)^{* *}\end{array}$ & $\begin{array}{c}0.002 \\
(0.000)^{* *}\end{array}$ \\
\hline Size of Ethnic Group & --- & $\begin{array}{c}1.985 \\
(0.077)^{* *}\end{array}$ & $\begin{array}{c}1.951 \\
(0.082)^{* *}\end{array}$ & $\begin{array}{c}1.894 \\
(0.117)^{* *}\end{array}$ \\
\hline Square of Size & --- & $\begin{array}{c}-2.064 \\
(0.138)^{* *}\end{array}$ & $\begin{array}{c}-1.979 \\
(0.148)^{* *}\end{array}$ & $\begin{array}{c}-1.876 \\
(0.188)^{* *}\end{array}$ \\
\hline Age group: $31-35$ & $\begin{array}{c}0.002 \\
(0.003)\end{array}$ & $\begin{array}{c}0.002 \\
(0.003)\end{array}$ & $\begin{array}{c}0.002 \\
(0.003)\end{array}$ & $\begin{array}{c}0.002 \\
(0.003)\end{array}$ \\
\hline Age group: $36-40$ & $\begin{array}{c}0.006 \\
(0.003)^{*}\end{array}$ & $\begin{array}{c}0.006 \\
(0.003)^{*}\end{array}$ & $\begin{array}{c}0.007 \\
(0.003)^{*}\end{array}$ & $\begin{array}{c}0.008 \\
(0.003)^{* *}\end{array}$ \\
\hline Speaks only English & $\begin{array}{c}-0.220 \\
(0.011)^{* *}\end{array}$ & $\begin{array}{c}-0.227 \\
(0.010)^{* *}\end{array}$ & $\begin{array}{c}-0.225 \\
(0.010)^{* *}\end{array}$ & $\begin{array}{c}-0.222 \\
(0.010)^{* *}\end{array}$ \\
\hline White race & $\begin{array}{c}-0.130 \\
(0.020)^{* *}\end{array}$ & $\begin{array}{c}-0.082 \\
(0.013)^{* *}\end{array}$ & $\begin{array}{c}-0.058 \\
(0.016)^{* *}\end{array}$ & $\begin{array}{l}-0.027 \\
(0.018)\end{array}$ \\
\hline Asian race & $\begin{array}{c}0.154 \\
(0.022)^{* *}\end{array}$ & $\begin{array}{c}0.280 \\
(0.013)^{* *}\end{array}$ & $\begin{array}{c}0.309 \\
(0.018)^{* *}\end{array}$ & $\begin{array}{c}0.268 \\
(0.024)^{* *}\end{array}$ \\
\hline U.S. born & $\begin{array}{c}-0.156 \\
(0.013)^{* *}\end{array}$ & $\begin{array}{c}-0.182 \\
(0.012)^{* *}\end{array}$ & $\begin{array}{c}-0.167 \\
(0.012)^{* *}\end{array}$ & $\begin{array}{c}-0.163 \\
(0.012)^{* *}\end{array}$ \\
\hline Veteran status & $\begin{array}{c}-0.047 \\
(0.004)^{* *}\end{array}$ & $\begin{array}{c}-0.042 \\
(0.003)^{* *}\end{array}$ & $\begin{array}{c}-0.039 \\
(0.003)^{*}\end{array}$ & $\begin{array}{c}-0.040 \\
(0.003)^{* *}\end{array}$ \\
\hline In metro area, central city & $\begin{array}{l}-0.012 \\
(0.009)\end{array}$ & $\begin{array}{c}0.007 \\
(0.006)\end{array}$ & $\begin{array}{c}0.006 \\
(0.006)\end{array}$ & $\begin{array}{c}0.003 \\
(0.006)\end{array}$ \\
\hline In metro area, outside central city & $\begin{array}{l}-0.010 \\
(0.008)\end{array}$ & $\begin{array}{l}-0.002 \\
(0.003)\end{array}$ & $\begin{array}{l}-0.001 \\
(0.004)\end{array}$ & $\begin{array}{l}-0.001 \\
(0.003)\end{array}$ \\
\hline $\begin{array}{l}\text { Region dummies } \\
\text { Ancestry dummies }\end{array}$ & $\begin{array}{l}\text { Yes } \\
\text { No }\end{array}$ & $\begin{array}{l}\text { Yes } \\
\text { No }\end{array}$ & $\begin{array}{l}\text { Yes } \\
\text { No }\end{array}$ & $\begin{array}{l}\text { Yes } \\
\text { Yes }\end{array}$ \\
\hline Observations & 238,711 & 238,711 & 238,711 & 238,711 \\
\hline
\end{tabular}

Notes: Robust standard errors are in parentheses and clustered on MSA $\times$ ancestry cells.

+ significant at $10 \%$; * significant at $5 \%$; ** significant at $1 \%$.

--- implies that the variable is not included in the specification. 
Table 4. Effects of Education on Endogamy by Immigrant Generation.

\begin{tabular}{|c|c|c|c|c|}
\hline Endogamy & $\begin{array}{l}\text { U.S. } \\
\text { Born }\end{array}$ & Foreign Born, All & $\begin{array}{c}\text { Foreign Born, Age at } \\
\text { arrival: } 0-10\end{array}$ & $\begin{array}{l}\text { Foreign Born, Age at } \\
\text { arrival: } 14-17\end{array}$ \\
\hline \multirow[t]{2}{*}{ Years of Education } & -0.005 & -0.001 & 0.001 & -0.008 \\
\hline & $(0.001)^{* *}$ & $(0.001)$ & $(0.002)$ & $(0.002)^{* *}$ \\
\hline \multirow[t]{2}{*}{ Mean Ethnic Education } & -0.013 & 0.001 & -0.030 & 0.007 \\
\hline & $(0.003)^{* *}$ & $(0.006)$ & $(0.013)^{*}$ & $(0.013)$ \\
\hline \multirow[t]{2}{*}{ Mean Ethnic Education-Mean Education } & -0.047 & -0.037 & -0.050 & -0.035 \\
\hline & $(0.007)^{* *}$ & $(0.007)^{* *}$ & $(0.017)^{* *}$ & $(0.014)^{*}$ \\
\hline \multirow{2}{*}{ Education $\times$ (Mean Ethnic Education-Mean Education) } & 0.004 & 0.001 & 0.002 & 0.000 \\
\hline & $(0.000)^{* *}$ & $(0.000)^{* *}$ & $(0.001)^{* *}$ & $(0.001)$ \\
\hline \multirow[t]{2}{*}{ Size of Ethnic Group } & 2.223 & 1.205 & 1.546 & 1.295 \\
\hline & $(0.122)^{* *}$ & $(0.102)^{* *}$ & $(0.199)^{* *}$ & $(0.208)^{* *}$ \\
\hline \multirow[t]{2}{*}{ Square of Size } & -2.112 & -1.201 & -1.433 & -1.159 \\
\hline & $(0.207)^{* *}$ & $(0.165)^{* *}$ & $(0.314)^{* *}$ & $(0.306)^{* *}$ \\
\hline \multirow{2}{*}{ Age group: 31-35 } & -0.001 & 0.014 & 0.019 & -0.001 \\
\hline & $(0.003)$ & $(0.006)^{*}$ & $(0.014)$ & $(0.013)$ \\
\hline \multirow[t]{2}{*}{ Age group: 36-40 } & 0.005 & 0.016 & 0.012 & -0.023 \\
\hline & $(0.003)+$ & $(0.006)^{*}$ & $(0.015)$ & $(0.013)+$ \\
\hline \multirow[t]{2}{*}{ Speaks only English } & -0.127 & -0.355 & -0.314 & -0.273 \\
\hline & $(0.010)^{* *}$ & $(0.016)^{* *}$ & $(0.016)^{* *}$ & $(0.038)^{* *}$ \\
\hline \multirow[t]{2}{*}{ White race } & -0.093 & 0.089 & -0.034 & 0.003 \\
\hline & $(0.014)^{* *}$ & $(0.033) * *$ & $(0.040)$ & $(0.054)$ \\
\hline \multirow[t]{2}{*}{ Asian race } & 0.186 & 0.283 & 0.201 & 0.186 \\
\hline & $(0.028)^{* *}$ & $(0.037)^{* *}$ & $(0.057)^{* *}$ & $(0.103)+$ \\
\hline \multirow[t]{2}{*}{ Veteran status } & -0.033 & -0.071 & -0.029 & -0.044 \\
\hline & $(0.003)^{* *}$ & $(0.011)^{* *}$ & $(0.017)+$ & $(0.030)$ \\
\hline \multirow[t]{2}{*}{ In metro area, central city } & 0.004 & -0.010 & 0.003 & -0.021 \\
\hline & $(0.008)$ & $(0.007)$ & $(0.017)$ & $(0.015)$ \\
\hline \multirow[t]{2}{*}{ In metro area, outside central city } & 0.005 & -0.015 & -0.005 & -0.008 \\
\hline & $(0.003)$ & $(0.006)^{* *}$ & $(0.013)$ & $(0.013)$ \\
\hline Region dummies & Yes & Yes & Yes & Yes \\
\hline Ancestry dummies & Yes & Yes & Yes & Yes \\
\hline Observations & 189,730 & 48,993 & 7,519 & 7,126 \\
\hline
\end{tabular}

Notes: Robust standard errors in parentheses and clustered on MSA $\times$ ancestry cells.

+ significant at $10 \%$; $*$ significant at $5 \%$; ** significant at $1 \%$. 
Table 5. Effects of Education on Endogamy by Race and Nativity.

\begin{tabular}{|c|c|c|c|c|c|c|}
\hline Endogamy & $\begin{array}{l}\text { White } \\
\text { Natives }\end{array}$ & $\begin{array}{c}\text { White } \\
\text { Foreign } \\
\text { Born } \\
\end{array}$ & $\begin{array}{c}\text { Hispanic } \\
\text { Natives }\end{array}$ & $\begin{array}{c}\text { Hispanic } \\
\text { Foreign } \\
\text { Born } \\
\end{array}$ & $\begin{array}{l}\text { Asian } \\
\text { Natives }\end{array}$ & $\begin{array}{c}\text { Asian } \\
\text { Foreign } \\
\text { Born } \\
\end{array}$ \\
\hline Years of Education & $\begin{array}{c}-0.004 \\
(0.001)^{* *}\end{array}$ & $\begin{array}{c}-0.007 \\
(0.002)^{* *}\end{array}$ & $\begin{array}{c}-0.009 \\
(0.003)^{* *}\end{array}$ & $\begin{array}{c}-0.007 \\
(0.002)^{* *}\end{array}$ & $\begin{array}{c}0.001 \\
(0.004)\end{array}$ & $\begin{array}{c}0.000 \\
(0.001)\end{array}$ \\
\hline Mean Ethnic Education & $\begin{array}{c}-0.011 \\
(0.003)^{* *}\end{array}$ & $\begin{array}{c}0.012 \\
(0.012)\end{array}$ & $\begin{array}{c}-0.023 \\
(0.009)^{* *}\end{array}$ & $\begin{array}{c}0.004 \\
(0.010)\end{array}$ & $\begin{array}{l}-0.027 \\
(0.021)\end{array}$ & $\begin{array}{l}-0.004 \\
(0.006)\end{array}$ \\
\hline Mean Ethnic Education-Mean Education & $\begin{array}{c}-0.038 \\
(0.009)^{* *}\end{array}$ & $\begin{array}{c}-0.109 \\
(0.016)^{* *}\end{array}$ & $\begin{array}{c}-0.020 \\
(0.014)\end{array}$ & $\begin{array}{c}-0.025 \\
(0.011)^{*}\end{array}$ & $\begin{array}{c}-0.023 \\
(0.041)\end{array}$ & $\begin{array}{c}-0.028 \\
(0.001)^{*}\end{array}$ \\
\hline Education $\times$ (Mean Ethnic Education-Mean Education) & $\begin{array}{c}0.004 \\
(0.001)^{* *}\end{array}$ & $\begin{array}{c}0.005 \\
(0.001)^{* *}\end{array}$ & $\begin{array}{c}0.003 \\
(0.001)^{* *}\end{array}$ & $\begin{array}{c}-0.001 \\
(0.001)\end{array}$ & $\begin{array}{c}0.003 \\
(0.002)\end{array}$ & $\begin{array}{c}0.002 \\
(0.000)^{* *}\end{array}$ \\
\hline Size of Ethnic Group & $\begin{array}{c}2.377 \\
(0.195)^{* *}\end{array}$ & $\begin{array}{c}2.116 \\
(0.327)^{* *}\end{array}$ & $\begin{array}{c}1.671 \\
(0.101)^{* *}\end{array}$ & $\begin{array}{c}1.205 \\
(0.119)^{* *}\end{array}$ & $\begin{array}{c}5.119 \\
(1.383)^{* *}\end{array}$ & $\begin{array}{c}2.671 \\
(0.419)^{* *}\end{array}$ \\
\hline Square of Size & $\begin{array}{c}-2.460 \\
(0.416)^{* *}\end{array}$ & $\begin{array}{c}-3.148 \\
(0.933)^{* *}\end{array}$ & $\begin{array}{c}-1.624 \\
(0.171)^{* *}\end{array}$ & $\begin{array}{c}-1.151 \\
(0.183)^{* *}\end{array}$ & $\begin{array}{c}-16.426 \\
(6.236)^{* *}\end{array}$ & $\begin{array}{c}-12.827 \\
(2.296)^{* *}\end{array}$ \\
\hline Age group: 31-35 & $\begin{array}{c}0.000 \\
(0.003)\end{array}$ & $\begin{array}{c}0.003 \\
(0.016)\end{array}$ & $\begin{array}{l}-0.003 \\
(0.016)\end{array}$ & $\begin{array}{c}0.015 \\
(0.009)\end{array}$ & $\begin{array}{c}-0.031 \\
(0.030)\end{array}$ & $\begin{array}{c}0.022 \\
(0.007)^{* *}\end{array}$ \\
\hline Age group: $36-40$ & $\begin{array}{c}0.005 \\
(0.003)\end{array}$ & $\begin{array}{c}0.039 \\
(0.014)^{* *}\end{array}$ & $\begin{array}{c}0.002 \\
(0.014)\end{array}$ & $\begin{array}{c}0.004 \\
(0.010)\end{array}$ & $\begin{array}{l}-0.021 \\
(0.029)\end{array}$ & $\begin{array}{c}0.026 \\
(0.008)^{* *}\end{array}$ \\
\hline Speaks only English & $\begin{array}{c}-0.047 \\
(0.012)^{* *}\end{array}$ & $\begin{array}{c}-0.349 \\
(0.019)^{* *}\end{array}$ & $\begin{array}{c}-0.272 \\
(0.014)^{* *}\end{array}$ & $\begin{array}{c}-0.220 \\
(0.027)^{* *}\end{array}$ & $\begin{array}{c}-0.349 \\
(0.028)^{* *}\end{array}$ & $\begin{array}{c}-0.457 \\
(0.025)^{* *}\end{array}$ \\
\hline Veteran status & $\begin{array}{c}-0.030 \\
(0.003)^{* *}\end{array}$ & $\begin{array}{c}-0.047 \\
(0.021)^{*}\end{array}$ & $\begin{array}{c}-0.057 \\
(0.013)^{* *}\end{array}$ & $\begin{array}{c}-0.094 \\
(0.019) * *\end{array}$ & $\begin{array}{c}0.011 \\
(0.042)\end{array}$ & $\begin{array}{c}-0.045 \\
(0.017)^{* *}\end{array}$ \\
\hline In metro area, central city & $\begin{array}{c}0.003 \\
(0.008)\end{array}$ & $\begin{array}{l}-0.010 \\
(0.017)\end{array}$ & $\begin{array}{c}0.023 \\
(0.016)\end{array}$ & $\begin{array}{c}-0.018 \\
(0.011)+\end{array}$ & $\begin{array}{c}-0.011 \\
(0.028)\end{array}$ & $\begin{array}{c}0.017 \\
(0.008)^{*}\end{array}$ \\
\hline In metro area, outside central city & $\begin{array}{c}0.005 \\
(0.003)\end{array}$ & $\begin{array}{l}-0.023 \\
(0.014)\end{array}$ & $\begin{array}{c}0.005 \\
(0.018)\end{array}$ & $\begin{array}{c}-0.027 \\
(0.010)^{* *}\end{array}$ & $\begin{array}{c}0.022 \\
(0.021)\end{array}$ & $\begin{array}{c}0.015 \\
(0.008)^{*}\end{array}$ \\
\hline $\begin{array}{l}\text { Region dummies } \\
\text { Ancestry dummies }\end{array}$ & $\begin{array}{l}\text { Yes } \\
\text { Yes }\end{array}$ & $\begin{array}{l}\text { Yes } \\
\text { Yes }\end{array}$ & $\begin{array}{l}\text { Yes } \\
\text { Yes }\end{array}$ & $\begin{array}{l}\text { Yes } \\
\text { Yes }\end{array}$ & $\begin{array}{l}\text { Yes } \\
\text { Yes }\end{array}$ & $\begin{array}{l}\text { Yes } \\
\text { Yes }\end{array}$ \\
\hline Observations & 175,052 & 7,794 & 10,313 & 22,405 & 2,094 & 17,890 \\
\hline
\end{tabular}

Notes: Robust standard errors are in parentheses and clustered on MSA $\times$ ancestry cells.

+ significant at $10 \%$; significant at $5 \%$; * significant at $1 \%$. 
Table 6. Spousal Differences in Schooling by Marriage Type.

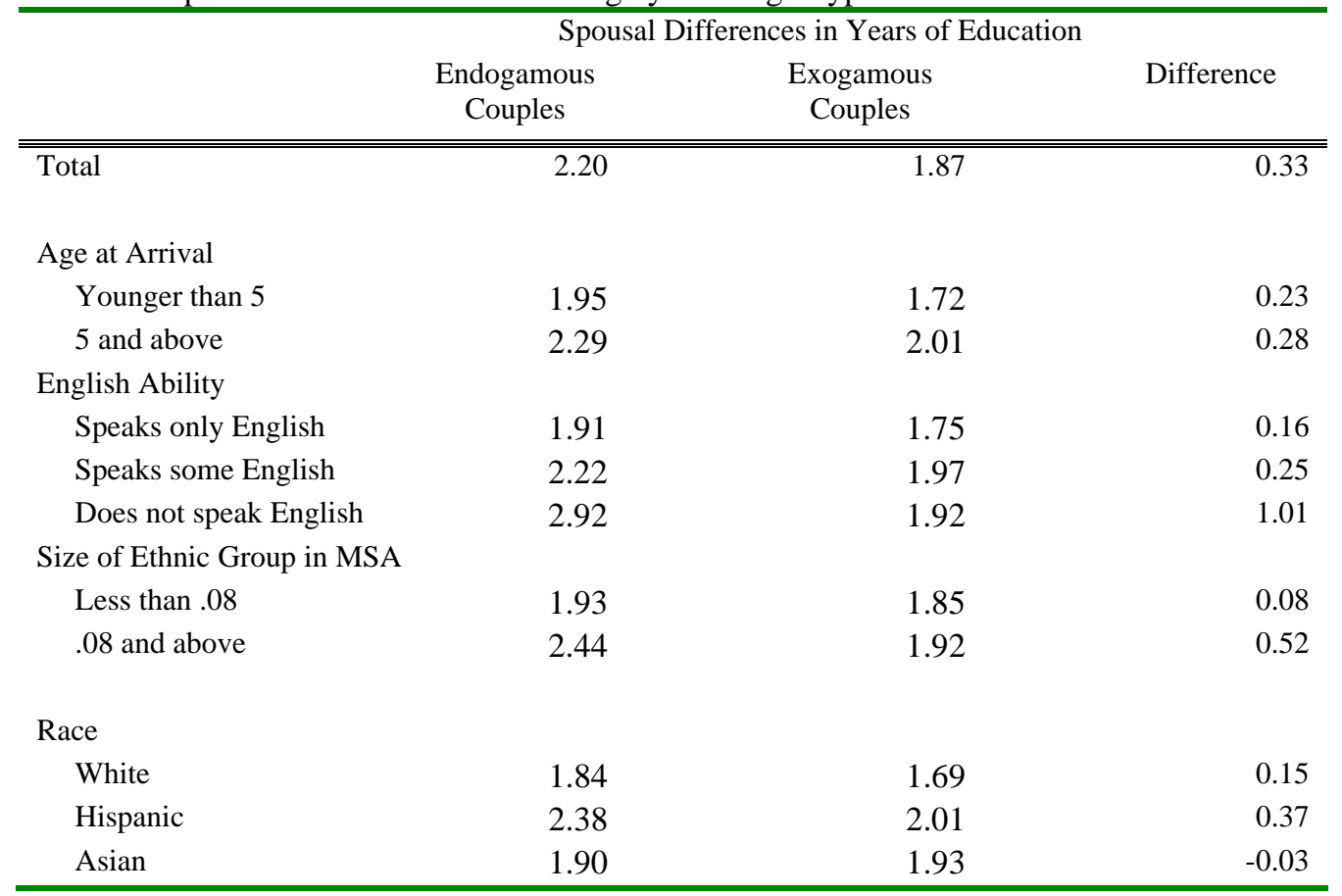

Notes: Figures are weighted. 


\section{APPENDIX B}

Years of education

Question: "What is the highest degree or level of school this person has completed?" Mark [X] One box. If currently enrolled, mark the previous grade of the highest degree achieved.

Mapping of educational qualifications to years of education a la Chiswick and DebBurman (2004).

No school completed - Zero years of education

$1^{\text {st }}-4^{\text {th }}$ grade (nursery school to $4^{\text {th }}$ grade) -2.5 years

$5^{\text {th }}-8^{\text {th }}$ grade -6.5 years

$9^{\text {th }}$ grade -9 years

$10^{\text {th }}$ grade -10 years

$11^{\text {th }}$ grade -11 years

$12^{\text {th }}$ grade (no diploma) -12 years

High school graduate (high school diploma or the equivalent, for example GED) - 12 years

Some college credit (but less than 1 year) - 13 years

Associate degree (for example: AA, AS)- 14.5 years

Bachelor's degree (for example: BA, AB, BS)- 16 years

Master's degree (for example: MA, MS, MEng, Med, MSW, MBA) - 18 years

Professional degree (for example, MD, DDS, DVM, LLB, JD) - 22 years

Doctorate degree (for example: $\mathrm{PhD}, \mathrm{EdD}$ ) -22 years

[The definition of school includes any nursery school, kindergarten, elementary school, any schooling leading toward a high school diploma or college degree].

\section{Ancestry dummies}

Question: "What is this person's ancestry or ethnic origin?"

It provides the respondent's self-reported ancestry or ethnic origin (first response). We distinguish 34 ancestry dummies.

European groups: Austrian, Belgian, Danish, Dutch, Finnish, French, German, Greek, Irish, Italian, Norwegian, Portuguese, Swedish, Swiss, Czechoslovakian, Hungarian, Lithuanian, Polish, Russian, Yugoslavian, Spaniard.

Mexican groups: Mexican, Mexican American, Nuevo Mexicano.

Hispanic groups: Hispanic, Spanish.

Central American groups: Guatemalan, Honduran, Nicaraguan, Salvadorian.

South American groups: Colombian, Ecuadorian, Peruvian.

West Indian groups: Dominican, Jamaican, Haitian.

Asian groups: Indian, Chinese, Filipino, Japanese, Korean, Vietnamese.

Other ancestries: Puerto Rican, Cuban.

\section{Race dummies}

We distinguish between 3 mutually exclusive race categories: Whites, Asians and Hispanics.

\section{Native born dummy}

Takes the value of 1 if the individual is U.S. born, 0 otherwise.

\section{Age of arrival}

Age of the individual minus years the individual has been in the U.S (years since migration in the U.S.).

\section{Age married}

Age of the individual minus the age of the eldest own child in the household. 


\section{Veteran status dummy}

Question: "Has this person ever served on active duty in the U.S. Armed Forces, military Reserves, on National Guard?” Active duty does not include training fore the Reserves or National Guard, but does include activation, for example, for the Persian Gulf War.

Equals to 1 if the individual if the individual served in the military forces of the U.S. (army, navy, air force, marine corps, or coast guard) in time of war or peace, 0 otherwise.

\section{English speaking dummy}

Equals 1 if the individual speaks English only, 0 otherwise.

\section{Age cohort dummies}

Equals 1 if in the age group 26-30, 0 otherwise.

Equals 1 if in the age group 31-35, 0 otherwise.

Equals 1 if in the age group 36-40, 0 otherwise.

\section{Region dummies}

Nine region dummies: New England division, Middle Atlantic division, East North Central, West North Central, South Atlantic division, East South Central division, West South Central division, Mountain division, Pacific division.

\section{Metro dummies}

It indicates whether the household was located within a metropolitan area. For households within metropolitan areas, it indicates whether the housing unit was within a metropolitan area's central city (or cities), or within the remainder of the metropolitan area.

Three metro area dummies: in metro area (central city), in metro area (outside central city), central city status unknown.

\section{Metropolitan Statistical Area}

Metropolitan areas are counties or combinations of counties centering on a substantial urban area. It identifies the metropolitan area where the household was enumerated, if that metropolitan area was large enough to meet confidentiality requirements. There are 283 identifiable MSAs in our sample.

\section{Size of ethnic group}

It is the ratio of the (numerator = number of individuals of each of the 34 ancestry groups in each MSA, denominator $=$ number of the whole U.S. population in each MSA). 